\title{
"Becoming-Woman-dog-goldfish-flower-molecular" and the "non-becoming-Québécois": Dissolution and Other Deleuzian Traversals in Flora Balzano's Soigne ta chute
}

\author{
Jana Evans Braziel
}

\begin{abstract}
Dans Soigne ta chute de Flora Balzano (1992), la narratrice se souvient d'une punition très violente qu'elle recevait lorsqu'elle était enfant où sa "fente" était écartée et remplie de piment broyé par sa mère qui est ainsi associée avec la douloureuse séparation et l'étouffement du sujet. Au premier abord, le roman semble inviter une lecture kristévienne en faisant de la langue supprimée de la narratrice, une langue maternelle. Toutefois, cette lecture est insuffisante pour la complexité de la caractérisation dans le roman. Braziel, dans son texte, souligne que dans la scène du souvenir, le corps violé de la fillette est déjà contigu avec les corps des soldats à l'extérieur de la maison, en train d'être mutilés pendant la guerre algérienne. Cette pluralité de l'identité de la narratrice est seulement le commencement d'une dissolution graduelle sous une forme où les oppositions intérieur/extérieur, moi/autre, humain/animal n'ont plus de sens. Braziel propose une lecture du processus sous l'angle du moléculaire de Deleuze.
\end{abstract}

An Algerian immigrant writer in Québec, Flora Balzano confounds various theoretical paradigms in her novel Soigne ta chute (1992) through her use of elusive narrative structures and amorphous subjectivities which cross national, genealogical and linguistic boundaries - from maghrébin to québécois. The text's narrative point of view is an aleatory one - perpetually shifting in perspective, tone, voice and location. A series of short, disjunctive monologues and vignettes recounting the protagonist's life as an immigrant in Montréal, Balzano's novel aptly mirrors diverse cultures of the immigrant populations of the city: distinctively, montréalité.

In the last decade, discourses on the notion of l'etranger or the relationship of the foreigner to the dominant culture have flourished in Québec, and specifically, in Montréal. According to Simon Harel, "la ville acquiert la faculté singulière de permettre l'exil." While Harel's engaging work on 
l'étranger, largely influenced by psychoanalytic theory, incisively theorizes the dislocations of the exile and the immigrant in relation to psychic alterity, I propose a more nomadic model, necessary for understanding the cacophony of voices and cultural dislocations of the immigrant québécoise, as reflected in Balzano's novel.

Initially, a Kristevan reading of this text seems appropriate. Its title, Soigne ta chute, coyly suggests the intimacy, the fecundity, the corporeality of the maternal. In the following, crucial passage (situated just before the text's Épilogue, but occurring at the beginning of the chronological story) the mother re-members a traumatic experience, in which her own mother brutally punishes her for wetting the bed sheets. The language of this memory and the imagery with which it is imbued resonate with Kristevan psychoanalytic overtones:

Elle ne me détache pas. Elle renifle, elle dit, tu pues. Elle me crache à la figure, elle me frappe en criant, saleté, salope, pourriture. Je pleure. Chut maman, chut maman. Elle remonte ma chemise sur mon visage, elle appuie fort de sa main dure, elle dit, tu la fermes ta sale gueule ou je t'étouffe?

Je me tais. J'attends qu'elle ait fini. Cen'est pas fini. Je ne vois pas ce qu'elle fait, mais je devine. Je l'entends farfouiller dans la cuisine. J'essaie de coller mes jambes l'une contrel'autre, mais jen'yarrive pas; je tire, mais jen'y yrrive pas. Soudain, elle écarte ma fente et la remplit de piment broyé. Ça brûle comme le sirocco qui hurle dans le ciel rouge. (111)

As the girl's labia are filled with crushed red pepper, the words on her lips are stopped: the girl/woman is locked within her own insular body in this asphyxiating "corps à corps" (115) with the mother. The spreading - "elle écarte ma fente" - and stuffing/sealing of the lips make silence the consequence of an act of mut(e)ilation by the mother, an act which violently literalizes the figure of labial "lips." Instead of being the originary moment of a split subjectivity, the scene is about a confounding of the interior/exterior divide established when, as Kristeva explicates (paraphrasing Freud), "le moi archaïque, narcissique, non encore délimité par le monde extérieur, projette hors de lui ce qu'il éprouve en lui-même comme dangereux ou déplaisant en soi, pour en faire un double étranger, inquiétant, démoniaque" (271). Something is psychoanalytically amiss here for instead of the phantasmatic projection outside, what we have is the 
implantation of something dangerous and disturbing by a malevolent force which, furthermore, is not clearly other. The mother is the bearer of the female genitalia culturally encoded as "quelque chose d'étrangement inquiétant" (Kristeva 274) and what she implants or reduplicates in her daughter is precisely this encoding of the female genitalia as the uncanny site of "forces maléfiques."

When, later, the mother fills the girl's mouth with bread, preventing her speech: "J'ai du mal à avaler. Deux tranches de pain trempées dans la morve et saupoudrées de honte" (111), the act resonates with this earlier connection between mutilation and muting. "Je mange tout, jusqu'à la dernière miette, je ne dis rien" (111).

Later in her life, this position is further reinforced: the young woman is denied an acting role as a nurse because of her French accent, but she is offered "le rôle muet d'la mère du p'tit malade" (34); ironically, she states "ma langue maternelle ça n'est pas le français mais le silence" (60). As if perpetuating this violent cycle of reticence, this mute-mutation of the female, the daughter specifies the mother's position - in surprisingly Kristevan terms - as one of negativity as well as silence: "Alors moi, s'il y a une chose qui m'écoeure dans la vie, c'est ma mère. Elle est nulle. Elle a toujours été nulle. Elle sera toujours nulle" (13).

On a closer reading, however, the psychoanalytic interpretation appears inadequate to field the historical and philosophical complexity of "hybrid" characterization in this novel. Immediately following the scene in which the girl-child is sexually, physically and verbally abused by her mother, the adult woman connects the pain that she felt during this moment to the suffering of the soldiers during the war of her childhood:

Dehors aussi c'est la guerre. Tout le monde se fait tuer. Ils explosent, pouf, leur corps tout démantibulé par les grenades. Moi, ça prend plus de temps, c'est tout... [I]ls se font attraper, ils se font déshabiller, ils se font pendre par les pieds, dans la rue, tout nus, et c'est la dernière fois qu'ils ont peur. On les voit qui traînent presque sur le trottoir, avec leurs doigts en moins parce qu' on a pris leurs bagues, ou plus de mains du tout parce qu'on a pris leurs montres. À l'envers, ils ont des yeux blancs fixés sur les crachats, et le ventre ouvert, les entrailles qui sortent et les mouches qui entrent.... Tout saignants. (111-12)

The dislocation and mutilation of the soldiers' bodies in the Algerian War 
echoes the sealing of the girl's lips with "piment broyé," the red pepper which functions as the mark of the Maghrebian cultural specificity which will ultimately cause her to be cut off her from her motherland and maternal dialect. Similarly tortured by the mother(land), the men are mutilated and finally muted through their own excised genitalia, a severed part turned against the self as silencing weapon: "Pour leur fermer la gueule définitivement, on a enfoncé leur zizi et leurs couilles dedans" (112).

The appendages close up not just the speaking orifice, but corporeal and psychical interiority itself. Even before the sealing of her lips, the girl's cries - like the soldier's - are animalistic, not human, thus complicating questions of voice and human expression, and the ostensible transparency of thoughts and words: "tout ce qui sort de ma gorge ce sont des petits cris de chien" (111). Appropriately, "gueule" (111) - a word connoting animality - is used in the same scene to refer to the site of the mouth. I will return momentarily to the issues of collapsed interiority and animality.

The dismemberment of the body parallels the dislocation of spatial and material origin which ensues in the novel's first-person narrative. The narrative begins with a granddaughter speaking about her mother in the "Prologue." The alinear cycles of the narrative move desultorily through time before the mother - the middle term in three generations of women - returns to her own childhood, eventually recalling the abusive act of her own mother. The narrative moves from a present "Prologue," through an inchoate middle, to a primary memory which erupts just before the "Épilogue." This movement progresses logically from "Prologue" to "Épilogue," but the prologos and the epilogos are counterlogically dislocated in space and time in relation to their origin: the prologos (before the 'word') suspended in a present that rushes back toward a frozen past in the epilogos (after the 'word'). The pre-verbal might be expected to precede the repression of the maternal, the splitting in the traumatic moment of abuse, with the entrance into language manifested in the epilogos of a Symbolic order. However, Balzano reverses, without categorically eluding, such a logic. Her deployment of nomadic positionality opens the text to a more fluid reading than that tendered by the psychoanalytic model.

I want to propose that the text's engagement with a collapsed (or dismantled) interiority and animality are fruitfully explored through a Deleuzian lens, a lens that has been recently appropriated by postcolonial theorists such as Robert Young and feminist cultural critics such as Rosi Braidotti for theo- 
rizing ethnic, national and linguistic hybridity. In Mille Plateaux, Deleuze and Guattari distinguish between the molaire (stratified, binaristic, static) and the moléculaire (volatile, multiplicitous, unfixed/unstable), explaining that in order to escape rigidity one must enter a molecular ligne de fuite initiated through a series of "becomings" that must begin with a devenir-femme, deterritorializing ultimately in a devenir-imperceptible:

On ne devient animal que moléculaire. On ne devient pas chien molaire aboyant, mais, en aboyant, si on le fait avec assez de coeur, de nécessité et de composition, on émet un chien moléculaire.... Oui, tous les devenirs sont moléculaires; l'animal, la fleur ou la pierre qu'on devient sont des collectivités moléculaires, des heccéitiés, non pas des formes, des objets ou sujets molaires qu'on connaît hors de nous, et qu'on reconnaît à force d'expérience ou de science, ou d'habitude. (337)

In A User's Guide to Capitalism and Schizophrenia: Deviations from Deleuze and Guattari, Brian Massumi elucidates this distinction between the molaire and the moléculaire. According to Massumi, the molar has become organized into a system that is "stabilized and homogenized," a concretion of "discrete particles ... correlated at a distance" (55), whereas the molecular exists only on the local or micropolitical level. At the molecular level, "only local connections between discrete particles exist" (54). Similarly, Ronald Bogue explains in Deleuze and Guattari, the organicity of the whole exists only at the molar or "aggregate level of organization"; conversely, the body without organs and desiring-machines operate at the local or molecular level (93).

In the same way that Balzano disrupts the narrative organization of the text, she discombobulates the molar organization of the narrator's "subjectivity": the daughter/mother/woman enters a process of "devenirfemme" which enacts a series of deterritorializations and molecular dissolutions of the self. This nomadic subject-position multifariously shifts from goldfish - "Je suis un poisson rouge" (51) - to a reterritorialization manifest in her attempt to "become-flower" (81-2), a line of flight entered through the eating of petals. The narrator-protagonist also speaks of a "becoming-automaton," a machinic assemblage of affective parts in a machine désirante: 
Je suis une autotomate. Autotomate vient du mot autotomie: mutilation réflexe d'une partie du corps chez certains animaux pour échapper à un danger, et du mot automate: toute machine animée par un mécanisme intérieur. Une autotomate n'est donc en aucun cas une auto qui à minuit tapant se transforme en tomate, mais un mot quej'ai inventé pour tenter de me définir, moi qui suis finie. (78)

My interpretation of subjectivity as a desiring-machine might seem problematic given Balzano's reference to an interiority: "toute machine animée par un mécanisme intérieur." However, the protagonist proceeds to describe her molecular state as one of immanence, not transcendence, one devoid of an interiority based on depth. She remarks, "Dès le départ, j'ai su que j'étais cuite. Intérieurement. Dans le fond, c'est moi le premier repas micro-ondes" (78). This self-defined interiority not only alludes to the pejorative Aristotelian definition of the feminine as matter and the theory of concoction in which woman serves as an oven in which the matter (derived from her menses) is baked into an offspring: it also renders this interiority as a plane of immanence contiguous with exteriority. Not surprisingly, the culinary mode is appropriately the micro/wave - representing dissolution to a greater degree than even the molecular: micro-ondes, in rapid movement.

The etymological emphasis of the above-quoted passage is evident "Autotomate vient du mot autotomie ... et du mot automate." The passage offers an etymology for "autotomate" which rhythmically suggests "autonomie," but is also ludicly confounded by Balzano's severance and disarrangement of the signifying chain - a dissolute signifying chain because it inaugurates its own dissolution. On the preceding page, the protagonist states, "Je m'appelle Pascale parce que je suis née le jour de Pâques" (77). This affirmative act of self-naming precedes the self-definitive passage on the automaton. Ironically, she calls herself 'Easter,' and the Easter-birthday necessarily evokes ideas of transcendence and spiritual rebirth; Balzano and her protagonist / desiring-machine playfully remind the reader of the inescapability of logos and logocentric thought even within a nomadic text, for the Christian idea of rebirth is found in the Gospel of John, which opens with the assertion that, "In the beginning was the Word." The protagonist states, "C'est la seule chose de logique qui me soit arrivée dans la vie" (77): afterward, nomadism prevails. The protagonist's dislocation from place of origin and birth becomes the mark of the cultur- 
al and linguistic hybridization of immigrant identity.

In Nomadic Subjects, Rosi Braidotti explores the feminist, the polyglot, the immigrant and the exile as forms of postmodern nomadism. In her terms, "nomadic shifts designate ... a creative sort of becoming; a performative metaphor that allows for otherwise unlikely encounters and unsuspected sources of interaction of experience and of knowledge" (6). The protagonist of Balzano's Soigne ta chute is a nomad in all of these senses, a subject whose "identity is a map of where s/he has already been" (Braidotti 14). The 'woman' provides her genea/logie, stating "Je suis née d'un père moitié italien moitié espagnol et d'un mère moitié polonaise moitié corse, en Algérie, pendant la guerre" (35). She is also the part-Italian, part-Spanish, part-Polish, part-Corsican, and perhaps part-Jewish immigrant from Algeria to Québec, who (after being rejected for an acting role as a nurse, because she is one of les p'tites françaises) maintains that "on ne devient pas québécoise" (33). When the protagonist's "pauvre petite grand-mère sénile" migrates from Africa to Québec, "son quatrième pays," she attempts to assimilate "au maximum" (39). The protagonist then derisively states, "Quand je dis son quatrième pays, c'est pour être polie. Parce que si je voulais être méchante, hein, je pourrais dire par example que le Québec n'est pas un pays. Hein?" (39). However, when her grandmother dies two months after migrating to Québec, the protagonist states that "elle l'a eu finalement le passeport rêvé, le passeport d'apatride" (39).

Apatride - without the boundaries of nation; the dislocated identity of the immigrant, the exile. Thus, the statement that on ne devient pas québécoise is ambivalent - suggesting both an estrangement from her pays ou société d'accueil, Québec, and a utopic resistance to the categories of citizenship and nationhood. She further describes her nomadic genea/logy as rhizomatic, without origin: "Mon arbre généalogique provient du croisement d'un tremble et d'un saule pleureur. L'immigrantus errantissimus qu'on l'appelle, en latin dans le texte. Ça pousse dans les sables mouvants. On ne peut descendre qu'en ligne brisée" (40-1). This rhizomatic, nonarborescent arbre is the cartography of her own nomadic becoming.

Finally, the process of becoming deterritorializes the molar realm - a realm manifest variously in the organisms of woman, goldfish, flower. Entering her lover Manuela's apartment, the protagonist glides into a state (perhaps drug-induced: Deleuze and Guattari do not preclude this possibility) in which she becomes aware, feels contiguous with and attempts to 
enter the molecular structure of the handrail in the hallway: "j'étais restee longtemps à caresser la rampe d'escalier et toutes ses molécules" (97); later as Manuela hands her a glass of water, she recollects, "je n'avais pas pu boire parce que je voyais tous les cristaux formés par les arrangements moléculaires" (98). In the interim, she becomes a body without organs and enters a state of indiscernibility, of imperceptibility:

J'étais assise dans la cuisine sur un chaise qui ne touchait pas à terre sans pourtant reposer sur du vide, car le vide n'était plus le vide et moi je n'étais plus du tout moi. J'étais tout sauf moi. Ou extrêmement moi, c'est pareil. (97)

As a corps sans organelles, she is unable to discriminate between le vide et le moi. The subject-position has been so affectively and so effectively dispersed throughout a molecular plane that she has become indiscernible to her/s e l f.

The "Épilogue" is the autodidactic making of the body without organs. Following the words of la prof, after "elle ... avait parlé d'énergie, de matière, de centre et d'essentiel" (115), the protagonist enters the process of self-creation - playing in the mud, playing in her shit - crafting the clay of her s/e/l/f/s/o/i, rather than God, mon Dieu, to whom the protagonist frequently and ironically speaks in the novel:

C'était exactement pour tout ça que je m'étais inscrite à son cours (POT 302), pour pouvoir jouer dans la terre comme dans mon caca. Pas que je veuille absolument repousser mon cri primalvenu, mais bon, il n'est jamais trop tard pour vivre une enfance heureuse. (115-16)

However, even this state of the body without organs is a volatile and impermanent one - and the protagonist risks the possibility of becoming an empty body without organs in a final fatalistic flight. She states, "je ne voulais pas absolument repousser mon cri primalvenu," but she also affirms that "je n'avais pas abandonné l'idée de la mater, la terre, d'en faire une belle grosse boule qui tournerait bien rond" (119). In the last sentence, la mater can be translated as the earth or as the Latin mater (matter), conveying the tension between the mastery of the molaire and the dispersion of power in the molecular body without organs, which Deleuze and Guattari describe in the following terms: 
Il n'est pas espace ni dans l'espace, il est matière qui occupera l'espace à tel ou tel degré - au degré qui correspond aux intensités produites. Il est la matière intense et non formée, non stratifée, la matrice intensive, l'intensité $=0$, mais il n'y a rien de négatif dans ce zéro-là, il n'y a pas $\mathrm{d}$ 'intensités négatives ni contraires. Matière égale énergie. Production du réel comme grandeur intensive à partir du zéro. (189-90)

In her attempt to establish a dialogue "entre la terre et moi," the protagonist realizes ultimately that "ce n'est pas sous mes doigts qu'elle était venue se former, la fameuse boule tant désirée, mais dans ma gorge. Parce que tout ce que je trouvais à lui dire, à la terre, c'était pardon" (120). At the end, she can only hope for a materiality in an inanimate state: "puis revenir galet, tonnelle, ruisseau, n'importe quoi de tranquille et de beau." Her final words in this dialogue are "la verité, ma terre, c'est que je me languis de toi" (120). A body without organs is desire, Deleuze and Guattari write, even if it is "désirer son propre anéantissement" (204): ultimately, le $\mathrm{CsO}$ vide (202), rather than a body without organs of plenitude.

The protagonist in Soigne ta chute precariously, wittily, and nomadically vacillates between $\log o s$ and nihilistic silence, between affirmative flight and annihilatory stasis, between the animate and the inanimate, the molaire and the moléculaire. The narrative resists rigidity and fixity: the protagonist, the woman, openly and agonistically defies being psychoanalyzed, politicized or socialized; not only does a psychoanalytic model fail to bring her into focus, she foils and frustrates being "analyzed" at all. She evades definitive interpretation: she is errant, nomadic, and elusive l'immigrantus errantissimus - leaving only traces.

\section{Works Cited}

Balzano, Flora. Soigne ta Chute. Montréal: XYZ Éditeur, 1992.

Bogue, Ronald. Deleuze and Guattari. London: Routledge, 1989.

Braidotti, Rosi. Nomadic Subjects: Embodiment and Sexual Difference in Contemporary Feminist Theory. New York: Columbia University Press, 1994.

Deleuze, Gilles and Félix Guattari. Mille Plateaux. Paris: Minuit, 1980.

Freud, Sigmund. "L'Inquiétante Étrangeté" et autres essais. Paris: Gallimard, 1985. 
Harel, Simon. "La parole orpheline de l'écrivain migrant." Montréal imaginaire, ville et littérature. Eds. Pierre Nepveu et Gilles Marcotte. Montréal: Fides, 1992. 373-418.

Kristeva, Julia. Étrangers à nous-mêmes. Paris: Gallimard, 1988.

Massumi, Brian. A User's Guide to Capitalism and Schizophrenia: Deviations from Deleuze and Guattari. Cambridge: A Swerve Edition, the MIT Press, 1992.

Young, Robert. "Colonialism and the Desiring Machine." Colonial Desire: Hybridity in Theory, Culture and Race. London: Routledge, 1995. 